\title{
Glucoamylase of Caulobacter crescentus CB15: cloning and expression in Escherichia coli and functional identification
}

\author{
Masayoshi Sakaguchi ${ }^{*}$, Yudai Matsushima ${ }^{1}$, Toshiyuki Nankumo', Junichi Seino ${ }^{1}$, Satoshi Miyakawa', Shotaro Honda', \\ Yasusato Sugahara ${ }^{1}$, Fumitaka Oyama ${ }^{1}$ and Masao Kawakita ${ }^{1,2}$
}

\begin{abstract}
The biochemical properties of the maltodextrin-hydrolyzing enzymes of cold-tolerant proteobacterium Caulobacter crescentus CB15 remain to be elucidated, although whose maltodextrin transport systems were well investigated. We cloned the putative glucoamylase of $C$. crescentus CB15 (CauloGA) gene. The CauloGA gene product that was expressed in E. coli was prone to forming inclusion bodies; however, most of the gene product was expressed in a soluble and active form when it was expressed as a fusion protein with Staphylococcus Protein A. The fusion protein was purified using an IgG Sepharose column and was identified as the active GA. The optimum temperature and $\mathrm{pH}$ for the activity of this GA toward maltotriose as a substrate were approximately $40^{\circ} \mathrm{C}$ and 5.0 , respectively, and a differential scanning fluorimetry (DSF) analysis revealed that the melting temperature $\left(T_{\mathrm{m}}\right)$ of CauloGA was $42.9^{\circ} \mathrm{C}$. The kinetic analyses with maltotriose and other maltodextrins as the substrates indicated that CauloGA has higher $k_{\text {cat }}$ and smaller $K_{m}$ values at $30^{\circ} \mathrm{C}$ with both substrates compared with other GAs at lower substrate concentration. However, the enzyme activities toward the substrates decreased as the substrate concentrations increased at concentrations higher than approximately 10 -fold the $K_{\mathrm{m}}$. The function-based identification of thermolabile Caulobacter GA contributes to the understanding of the maltodextrin-degradation system of $C$. crescentus as well as the bacterial GA's function-structure relationship.
\end{abstract}

Keywords: Cloning; Expression; Thermolabile glucoamylase; Characterization; Subsite affinity; Inhibition

\section{Introduction}

Caulobacter crescentus is a Gram-negative bacterium that can live in oligotrophic environments (Poindexter 1964). In Caulobacter sp. two groups of polysaccharidehydrolyzing enzymes were reported to date: the cellulases including endoglucanase, exoglucanase and $\beta-(1 \rightarrow 4)$-glucosidase (Song et al. 2013), and the $\beta$-xylosidases, xylosidase I and II (Graciano et al. 2012; Corrêa et al. 2012). In addition, the maltodextrin transport protein, MalA ( $c c 2287$ gene product), was induced by either maltose or maltodextrins, and transported maltodextrins ranging from maltose to maltopentaose (Neugebauer et al. 2005). Investigations of the metabolism of maltodextrins including starch and of the enzymes involved in the

\footnotetext{
* Correspondence: bt11532@ns.kogakuin.ac.jp

'Department of Applied Chemistry, Kogakuin University, 2,665-1 Nakano-cho, Hachioji, Tokyo 192-0015, Japan

Full list of author information is available at the end of the article
}

maltodextrin metabolism are definitely required, and outcome from such investigations would help in understanding the carbohydrate metabolism of Caulobacter.

In the malA gene cluster, there are six genes, $c c 2282$, $c c 2283, c c 2284, c c 2285, c c 2286$ and $c c 2287$ that are also described as MalS, MalY, MalI, an $\alpha$-amylase family protein, another $\alpha$-amylase family protein and MalA, resepectively (Neugebauer et al. 2005; Lohmiller et al. 2008). Nierman et al. (2001) who reported the complete genomic sequence of $C$. crescentus CB15, also known as Caulobacter vibrioides, tentatively assigned the $c c 2282$ gene to a putative glucoamylase (GA) gene based on similarity with other GA genes without functional evidence.

Glucoamylase (GA) is classified to the glycoside hydrolase $(\mathrm{GH})$ family 15 in the CAZy database (carbohydrate active enzymes database, http://www.cazy.org/). GA produces glucose from starch and is important in industry. This enzyme releases $\beta$-D-glucose from the non- 
reducing end of starch, glycogen and related oligo- and polysaccharides. GA shows a strong preference for the $\alpha$ - $(1 \rightarrow 4)$-linkages over the $\alpha-(1 \rightarrow 6)$-linkages. Eukaryotic GAs, particularly Aspergillus GA, have been extensively investigated (Coutinho and Reilly 1997; Kumar and Satyanarayana 2009). Bacterial GAs have also been studied, though less extensively than the fungal enzymes. Despite the similarity in the catalytic function and the overall structure of the catalytic domains, the similarity of the amino acid sequences is low between eukaryotic GAs and bacterial GAs. The catalytic properties of GA from thermophilic Clostridia were studied in considerable detail (Ohnishi et al. 1992; Ohnishi et al. 1994; Ducki et al. 1998; Ganghofner et al. 1998; Aleshin et al. 2003), and the three-dimensional structure of Thermoanaerobacterium thermosaccharolyticum GA (TtGA) was determined (Aleshin et al. 2003). Properties of GAs from thermophilic archaea were also reported (Uotsu-Tomita et al. 2001; Serour and Antranikian 2002; Dock et al. 2008, Kim et al. 2004).

The deduced amino acid sequence of the $c c 2282$ gene showed $47 \%$ similarity to that of both TtGA and Clostridium sp. G0005 GA (CGA, ClostGA), and the gene is registered in the CAZy database as CcGA (CauloGA) which belongs to the GH 15 family. However, the assignment remains tentative, since the gene product has not been functionally characterized, and since the deduced amino acid sequence showed $46 \%$ similarity to that of an N-terminal and a catalytic domains of Arthrobacter globiformis I42 glucodextranase (AgGDase), a GH 15 family enzyme (Mizuno et al. 2004). It is therefore important to examine whether the gene product in fact represents GA. The conclusive identification of Caulobacter GA may contribute to the understanding of the maltodextrin-degradation system of $C$. crescentus as well as the bacterial GA's function-structure relationship by adding a thermolabile member to those well characterized thermophilic group members. In this report, we cloned the putative GA gene (cc2282) from C. crescentus CB15, expressed it in E. coli and identified the gene product as a GA from Caulobacter (CauloGA) based on its functional properties.

\section{Materials and methods}

\section{Bacterial strains and growth media}

Caulobacter crescentus CB15 (ATCC No. 19089) was obtained from the American Type Culture Collection (ATCC). The E. coli strains used as the expression hosts and the gene engineering hosts were BL21 (DE3), DH5 $\alpha$, HB101, JM109, MV1184, Origami (DE3) and Tuner (DE3).

LB medium (1\% Bacto Tryptone, 0.5\% Bacto Yeast extract, $1 \% \mathrm{NaCl}, \mathrm{pH} 7.0$ ) was used for culturing E. coli in the genetic engineering and in the preculture for protein expression. The solid medium contained 1.5\% agar.
Ampicillin $(50 \mu \mathrm{g} / \mathrm{ml})$ was added to the medium as needed.

\section{Gene cloning and chemical reagents}

Genetic engineering experiments were performed according to the procedure described by Sambrook and Russell (2001). The enzymes used for genetic engineering were purchased from TAKARA BIO INC. (Shiga, Japan) and used according to the manufacturer's instructions. Bacto Tryptone, Bacto Yeast extract and peptone were purchased from Becton, Dickinson and Company (Franklin Lakes, NJ, USA). Other reagents and oligosaccharides used as substrates were of the highest quality available from Wako Pure Chemicals (Osaka, Japan) and SigmaAldrich (St. Louis, MO, USA), unless otherwise specified.

\section{Cloning of the GA gene from C. crescentus CB15 and construction of the expression plasmids}

C. crescentus CB15 was grown in Caulobacter medium (peptone, 2.0 g; yeast extract, $1.0 \mathrm{~g} ; \mathrm{MgSO}_{4} \cdot 7 \mathrm{H}_{2} \mathrm{O}, 0.2 \mathrm{~g}$ in 1 liter) at $30^{\circ} \mathrm{C}$ for $2-3$ days, and the genomic DNA was extracted using ISOPLANT II (Nippon Gene, Tokyo, Japan).

PCR was performed as follows: 1 cycle at $94^{\circ} \mathrm{C}$ for $2 \mathrm{~min}$ followed by 30 cycles of the sequence at $94^{\circ} \mathrm{C}$ for $15 \mathrm{~s}, 63^{\circ} \mathrm{C}$ for $30 \mathrm{~s}$ and $68^{\circ} \mathrm{C}$ for 2.5 min were performed, using $25 \mathrm{ng}$ of the genomic DNA as a template, with the forward primer 5' $5^{\prime}$-CGCGGATCCGCGATGCGCACGT TGAAAAC-3', and the reverse primer $5^{\prime}$-GGAATT CCTAGCGCGCGTACCGCGC-3' (the BamHI and Eco RI restriction sites are underlined), and the PCR product was cloned into the BamHI and EcoRI sites of pUC119 vector to give pUC119-CauloGA. Next, PCR was performed using the pUC119-CauloGA as a template, with the forward primer 2, 5'-GCGAATTCGGCGCCTACGACCTGGGCCTATTCG-3', and the reverse primer 2, 5'-CGGGATCCCTAGCGCGCGTACCGCGCCTTTAC GGG-3' (the EcoRI and BamHI sites, respectively, are underlined), to remove a putative signal peptide sequence that was predicted by SignalP (http://www.cbs. dtu.dk/services/SignalP/). The amplified PCR product was cloned into the EcoRI and BamHI site of the pEZZ18 vector (GE Healthcare, Tokyo, Japan) to yield the expression vector, pEZZ18-CauloGA. Expression vectors, pCold I-CauloGA and pCold TF-CauloGA, were constructed similarly using the pCold vectors (TAKARA) and pUC119-CauloGA plasmid. The nucleotide sequences were confirmed with the Applied Biosystems 3130 Genetic Analyzer (Applied Biosystems, Foster City, CA, USA).

The nucleotide sequence of CauloGA is available in the DDBJ/EMBL/GenBank database under the accession number AB813000. 


\section{Expression, purification and activity measurement of CauloGA}

The E. coli that was transformed with the pEZZ18CauloGA expression plasmid was precultured overnight in $\mathrm{LB}$ medium at $30^{\circ} \mathrm{C}$, and the preculture was inoculated in fresh $2 \times$ YT-medium (1.6\% Bacto Tryptone, 1\% Bacto Yeast extract, $0.5 \% \mathrm{NaCl}, \mathrm{pH} 7.0$ ) at $30^{\circ} \mathrm{C}$ for $24 \mathrm{~h}$, harvested by centrifugation, suspended in $20 \mathrm{mM}$ Tris$\mathrm{HCl}(\mathrm{pH} 7.0)$ containing $0.5 \mathrm{M} \mathrm{NaCl}$ and sonicated on ice using a Ultrasonic disruptor UD-201 (TOMY SEIKO, Tokyo, Japan). The supernatant obtained from the crude extract by centrifugation for $20 \mathrm{~min}$ at $20,000 \times g$ was adsorbed onto an IgG Sepharose column (GE Healthcare, Tokyo, Japan) that was equilibrated with TS buffer [50 mM Tris- $\mathrm{HCl}$ (pH 7.6) containing $150 \mathrm{mM} \mathrm{NaCl}$. The bound fusion proteins were eluted with TS buffer containing 40\% (v/v) 1,4-dioxan (Kumari and Gupta 2012). The purity of CauloGA was confirmed by $9 \%$ SDS-PAGE (Laemmli 1970). The fraction containing the active enzyme was dialyzed against $20 \mathrm{mM}$ Tris- $\mathrm{HCl}$, $0.5 \mathrm{M} \mathrm{NaCl}(\mathrm{pH} 7.0)$, and the purified protein was stored at $4^{\circ} \mathrm{C}$.

The enzyme activity was measured at $40^{\circ} \mathrm{C}$ in $50 \mathrm{mM}$ acetate buffer ( $\mathrm{pH}$ 5.0) with $0.9 \mathrm{mM}$ maltotriose as a substrate unless otherwise specified. The enzyme solution $(50 \mu \mathrm{l})$ was added to $450 \mu \mathrm{l}$ of the substrate solution, and the reaction mixture was incubated for an appropriate period. To halt the reaction, $50 \mu \mathrm{l}$ aliquots of the mixture were removed from the reaction mixture and mixed with $450 \mu \mathrm{l}$ of the stop solution, $1 \mathrm{M}$ Tris$\mathrm{HCl}(\mathrm{pH} 7.0)$, at appropriate intervals, and the initial rate was estimated from the initial slope of the reaction time course. The amount of glucose liberated from the substrate was determined with the F-kit D-glucose (Roche Diagnostics Gmbh, Mannheim, Germany) using the glucose standard curve as a reference. One unit of GA was defined as the amount of the enzyme that liberates $1 \mu \mathrm{mol}$ of glucose from the substrate in 1 minute. The protein concentration was measured using the micro-assay method (Bio-Rad Laboratories, Hercules, CA, USA), which is based on the Bradford method (Bradford 1976), using bovine serum albumin as a standard.

\section{Polyclonal antibody against the CauloGA gene product expressed in $E$. coli as an inclusion body}

The (His) ${ }_{6}$-tagged CauloGA was expressed in E. coli as an inclusion body using the pCold I vector system (TAKARA). The inclusion bodies were dissolved in $20 \mathrm{mM}$ Tris- $\mathrm{HCl}$ containing $6 \mathrm{M}$ guanidine hydrochloride, and the denatured CauloGA protein was purified on HisTrap ${ }^{\text {rs }} \mathrm{HP}$ (GE Healthcare) and the purified denatured CauloGA was used as the antigen to raise the rabbit anti- CauloGA antibody that was prepared by TAKARA.

\section{Western blotting analysis of CauloGA}

The CauloGA expressed in E. coli using the pEZZ18CauloGA expression plasmid was detected according to the procedure described in a previous report (TakeshimaFutagami et al. 2012). The CauloGA protein was detected using anti-CauloGA antibody and the HRP-conjugated goat anti-rabbit IgG $(\mathrm{H}+\mathrm{L})$ antibody (Invitrogen, Carlsbad, CA, USA) as the primary and the secondary antibodies, respectively. The bound antibodies were detected using the SuperSignal West Dura Trial Kit (Thermo Scientific, Rockford, IL, USA).

\section{Determination of the anomer type of the products of the CauloGA reaction}

Maltotriose as a substrate was dissolved in $\mathrm{D}_{2} \mathrm{O}$ containing $50 \mathrm{mM}$ 2-morpholinoethanesulfonic acid (MES)$\mathrm{NaOH}$ ( $\mathrm{pH}$ 6.0). The enzyme was mixed with $4.5 \mathrm{mM}$ maltotriose and incubated at $30^{\circ} \mathrm{C}$. At the appropriate reaction time, the ${ }^{1} \mathrm{H}-\mathrm{NMR}$ spectra were measured using a JNM-ECX-400 (JEOL, Tokyo, Japan) spectrometer. The chemical shifts were referenced to 2,2-dimethyl-2-silapentane-5-sulfonate (DSS) (Cambridge Isotope Laboratories, Inc., Andover, MA, USA), as the internal standard.

\section{Measurement of temperature- and $\mathrm{pH}$-dependence of the} activity, heat stability and $\mathrm{pH}$ stability of CauloGA

The temperature-dependence of the CauloGA activity was examined by measuring the initial rate as described above, at $15,20,25,30,35,40$ and $45^{\circ} \mathrm{C}$. To determine the heat stability of CauloGA, the enzyme solution was incubated at various temperatures $\left(4-60^{\circ} \mathrm{C}\right.$ ) for $60 \mathrm{~min}$ and cooled quickly, and the remaining activity was measured. The pH-dependence of the CauloGA activity was determined by measuring the initial rate at different $\mathrm{pH}$ values, ranging from $\mathrm{pH} 3.5$ to 11 , using $0.9 \mathrm{mM}$ maltotriose as a substrate in various buffers as follows: $50 \mathrm{mM}$ acetate buffer ( $\mathrm{pH}$ 3.5-6.0), $50 \mathrm{mM}$ MES-NaOH buffer (pH 5.0-7.0), $50 \mathrm{mM}$ Tris- $\mathrm{HCl}$ buffer ( $\mathrm{pH} 7.0-9.0)$ or $50 \mathrm{mM}$ carbonate- $\mathrm{NaOH}$ buffer $(\mathrm{pH} 10-11)$. To study the pH-stability of CauloGA, the enzyme solution was placed in various buffers $(\mathrm{pH} 3.5-11)$ at $4^{\circ} \mathrm{C}$ for $60 \mathrm{~min}$, and the remaining activity was measured.

\section{Differential scanning fluorimetry (DSF) analysis}

The experiment was performed using a Real Time PCR System (Mx3005p, Agilent Technologies, Santa Clara, CA, USA) and MxPro Software (Agilent Technologies). Tubes containing a mixture of $39 \mu \mathrm{l}$ of a protein solution and $1 \mu$ l of Sypro Orange (Invitrogen) diluted to 100 -fold with dimethyl sulfoxide were set in the PCR instrument and were subjected to the temperature scan at 
$1^{\circ} \mathrm{C} \min ^{-1}$ from $25^{\circ} \mathrm{C}$ to $95^{\circ} \mathrm{C}$. The filter configurations were customized to accommodate the optimal excitation and emission wavelengths for Sypro Orange (Ex: 492/ Em: $610 \mathrm{~nm}$ ). The inflection points of the transition curve, indicating the melting temperatures $\left(T_{\mathrm{m}}\right)$ of the protein, were estimated from the sigmoidal curves of the fluorescence intensity using the Boltzmann equation and a graphics software package (DeltaGraph ver. 6, Nihon Poladigital K.K., Tokyo, Japan), according to the method of Niesen et al. (2007).

\section{Results}

\section{Cloning of the CauloGA gene from Caulobacter crescentus} $\mathrm{CB} 15$ and its expression in the soluble form in $E$. coli

To obtain the CauloGA gene (the $c c 2282$ genomic region) from C. crescentus CB15, the forward and reverse primers were designed based on the report by Nierman et al. (2001). The nucleotide sequence of the cloned gene revealed two $\mathrm{T}$ for $\mathrm{C}$ substitutions at the positions 945 and 1,656 compared with the sequence reported by Nierman et al. (2001), but the deduced amino acid sequence was not affected by these base substitutions (Additional file 1: Figure S1).

Despite attempts to obtain an active CauloGA protein using pET vectors (e.g. pET21, pET28 or pET32; Novagen, Madison, WI, USA) and chaperon-coexpression vectors (TAKARA) together with various $E$. coli hosts, CauloGA was not obtained in a soluble form. When we tested the pCold TF vector system (TAKARA), the CauloGA protein was expressed in a soluble form but was completely inactive in hydrolyzing maltotriose. Although most of the expressed CauloGA protein formed inclusion bodies using the pCold I vector, a small amount of CauloGA protein was recovered in the soluble fraction in DH5 $\alpha$ and JM109, and the protein was proved to be catalytically active. This provides the rationale for using the insoluble CauloGA protein in inclusion bodies as an antigen to raise an anti-CauloGA antibody.

Finally, the CauloGA gene was recloned into the pEZZ18 vector, and active CauloGA was obtained in the soluble form in E. coli HB101 cells without IPTG induction at $30^{\circ} \mathrm{C}$. In this system, CauloGA was available as a fusion enzyme in which Staphylococcus Protein A was fused at the N-terminal end of the CauloGA (Figure 1A). The fusion protein, ProteinA-CauloGA, was soluble, and the maltotriose-hydrolyzing activity was detected entirely in the cell homogenates. The expressed ProteinACauloGA fusion protein was purified by IgG Sepharose to give a single band upon SDS-PAGE/Western blotting analysis (Figures $1 \mathrm{~B}$ and $1 \mathrm{C}$ ).

\section{Analysis of the CauloGA reaction products}

Figure 2 shows the thin-layer chromatogram of the products that were released by the CauloGA using

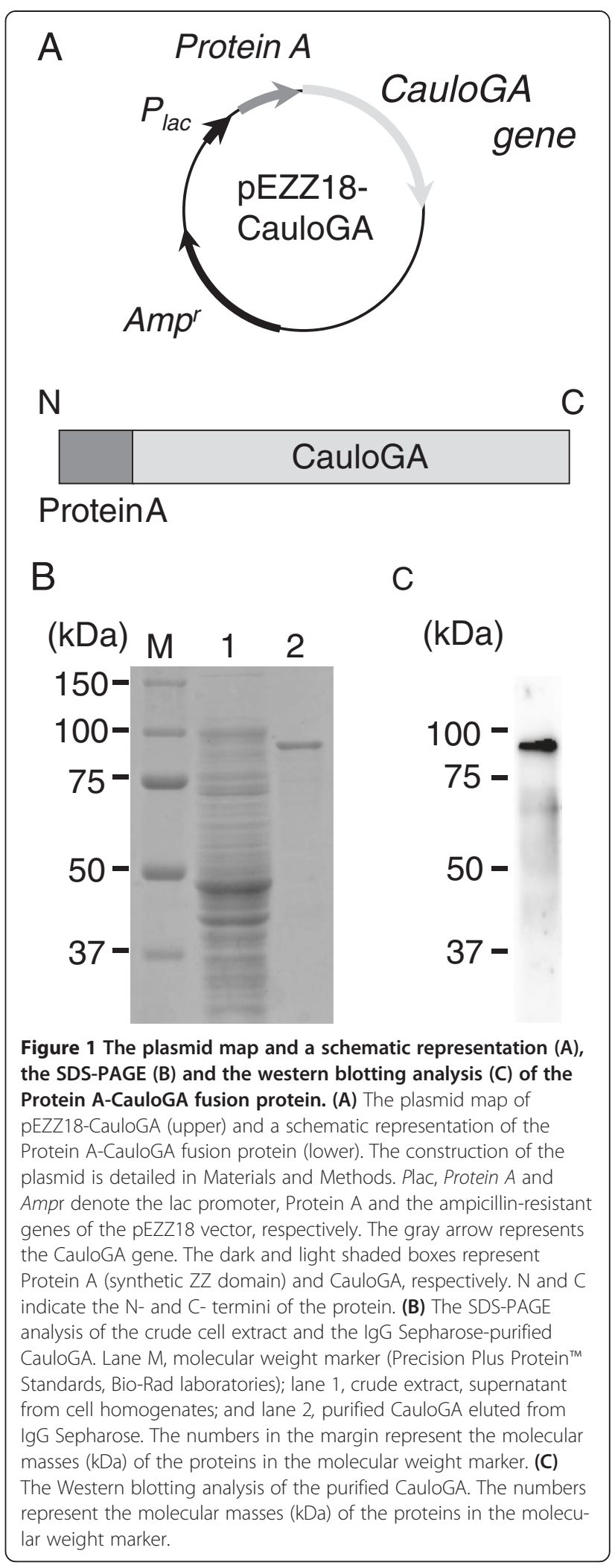



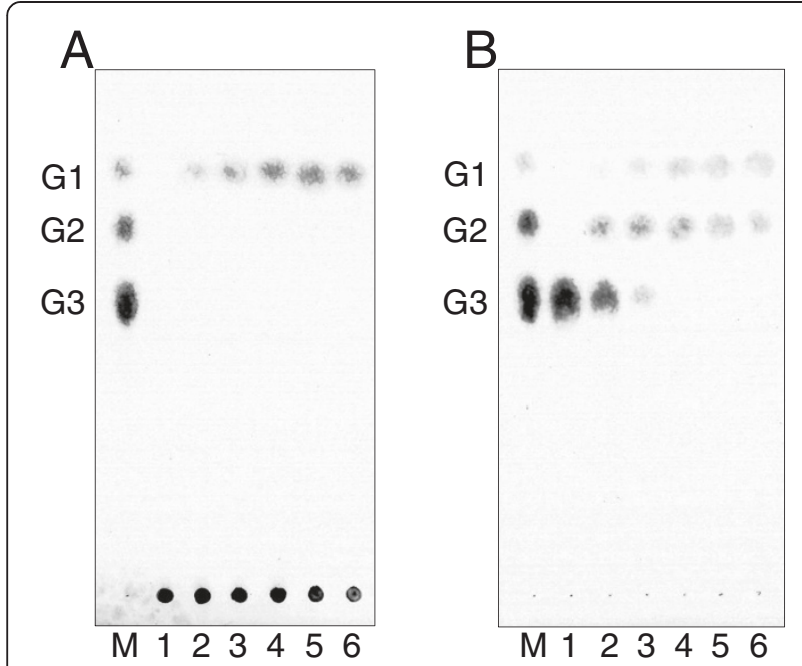

Figure 2 Analysis of the CauloGA reaction products with starch $(0.45 \%)(A)$ and maltotriose $(4.5 \mathrm{mM})(B)$ as the substrates. The reaction was performed at $30^{\circ} \mathrm{C}$ in $50 \mathrm{mM}$ acetate buffer $(\mathrm{pH} 4.5)$, halted by boiling, and the products were analyzed by thin-layer chromatography (TLC) on a Silica gel $60 \mathrm{~F}_{254}$ (Merck, Whitehouse Station, NJ, USA) with 1-butanol/ethanol/water (5:5:2, v/v/v) as the solvent, and the carbohydrate spots were detected as chars by spraying the $\mathrm{H}_{2} \mathrm{SO}_{4}$ /methanol $(5: 95, \mathrm{v} / \mathrm{v})$ solution. $\mathrm{G} 1, \mathrm{G} 2$ and $\mathrm{G} 3$ glucose, maltose and maltotriose, respectively. Lane M, glucose standard; lane 1, no enzyme added; lane 2 to 6 , the products obtained after hydrolysis for $5 \mathrm{~min}, 10 \mathrm{~min}, 15 \mathrm{~min}, 30 \mathrm{~min}$ and 60 min, respectively.

soluble starch (Figure 2A) and maltotriose (Figure 2B) as the substrates. Glucose was the sole product of the starch hydrolysis by the CauloGA, and the amount of glucose increased as a function of the reaction time. With maltotriose as the substrate, glucose and maltose were initially produced, and then, maltose was further hydrolyzed to yield glucose. These results suggested that CauloGA behaved as an exo-glucosyl hydrolase.

The anomer type of the products released from maltotriose by the CauloGA reaction was determined by ${ }^{1} \mathrm{H}-$ NMR analysis. The intensities of both the $\beta-\mathrm{H}(4.6 \mathrm{ppm})$ and $\alpha-\mathrm{H}(5.2 \mathrm{ppm})$ peaks increased with the reaction time, but the increase of the $\beta-\mathrm{H}(4.6 \mathrm{ppm})$ peak was more pronounced (Gloster et al. 2008). This is unlike the pattern obtained when $\alpha$-glucosidase (Sigma-Aldrich) was used as a control, and we concluded that the CauloGA produced glucose from maltotriose in the form of the $\beta$-anomer (Additional file 2: Figure S2A and S2B).

\section{Effects of the temperature and $\mathrm{pH}$ on the CauloGA activity}

The dependence of CauloGA activity on the temperature was examined using $0.9 \mathrm{mM}$ maltotriose in $50 \mathrm{mM}$ acetate buffer ( $\mathrm{pH}$ 5.0) at temperatures ranging from 10 to $45^{\circ} \mathrm{C}$. Figure $3 \mathrm{~A}$ shows that the activity of the CauloGA was maximal at approximately $40^{\circ} \mathrm{C}$. The activity of the

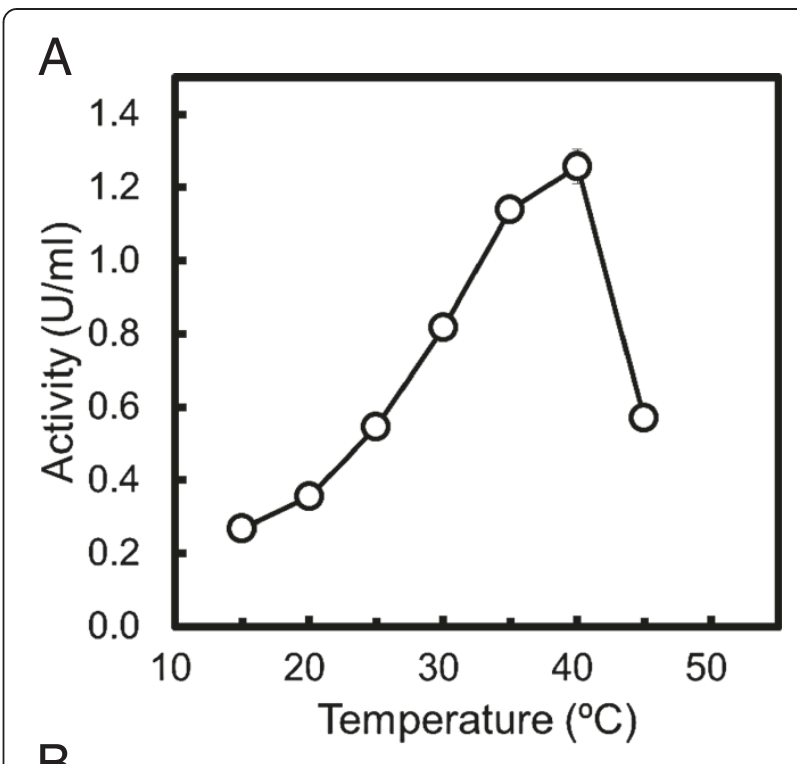

$\mathrm{B}$

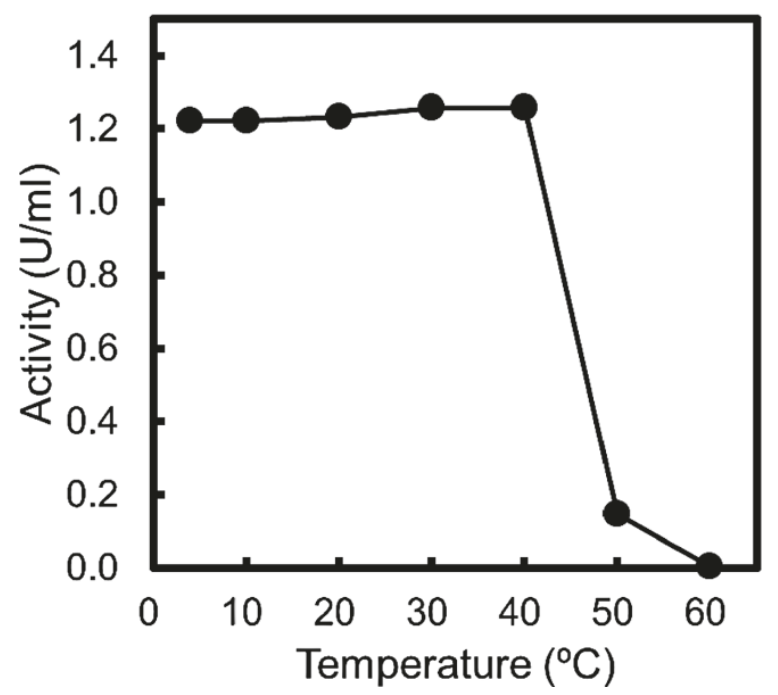

Figure 3 Effects of temperature on the CauloGA activity (A, open circle) and stability (B, closed circle). (A) The activity was measured at various temperatures $\left(15-40^{\circ} \mathrm{C}\right)$. (B) CauloGA was incubated at various temperatures $\left(4-60^{\circ} \mathrm{C}\right)$ for $60 \mathrm{~min}$, and the remaining activity was measured. The values are represented as enzyme activity. Experiments were carried out in triplicate.

CauloGA that remained after heat treatment for $60 \mathrm{~min}$ in a range of 4 to $60^{\circ} \mathrm{C}$ was determined at $40^{\circ} \mathrm{C}$ with maltotriose as a substrate; the results are shown in Figure 3B. The activity of the CauloGA remained stable for $60 \mathrm{~min}$ at temperatures ranging from 4 to $40^{\circ} \mathrm{C}$, but was almost completely lost at $50^{\circ} \mathrm{C}$ for $60 \mathrm{~min}$. This result was consistent with the results of the DSF analysis of the CauloGA, which gave a $T_{\mathrm{m}}$ value of $42.9^{\circ} \mathrm{C}$ (Additional file 3: Figure S3).

Figure 4A illustrates the $\mathrm{pH}$-dependence of the CauloGA activity. CauloGA was optimally active at $\mathrm{pH} 5$ to 6 and remained active over a broad $\mathrm{pH}$ range, 

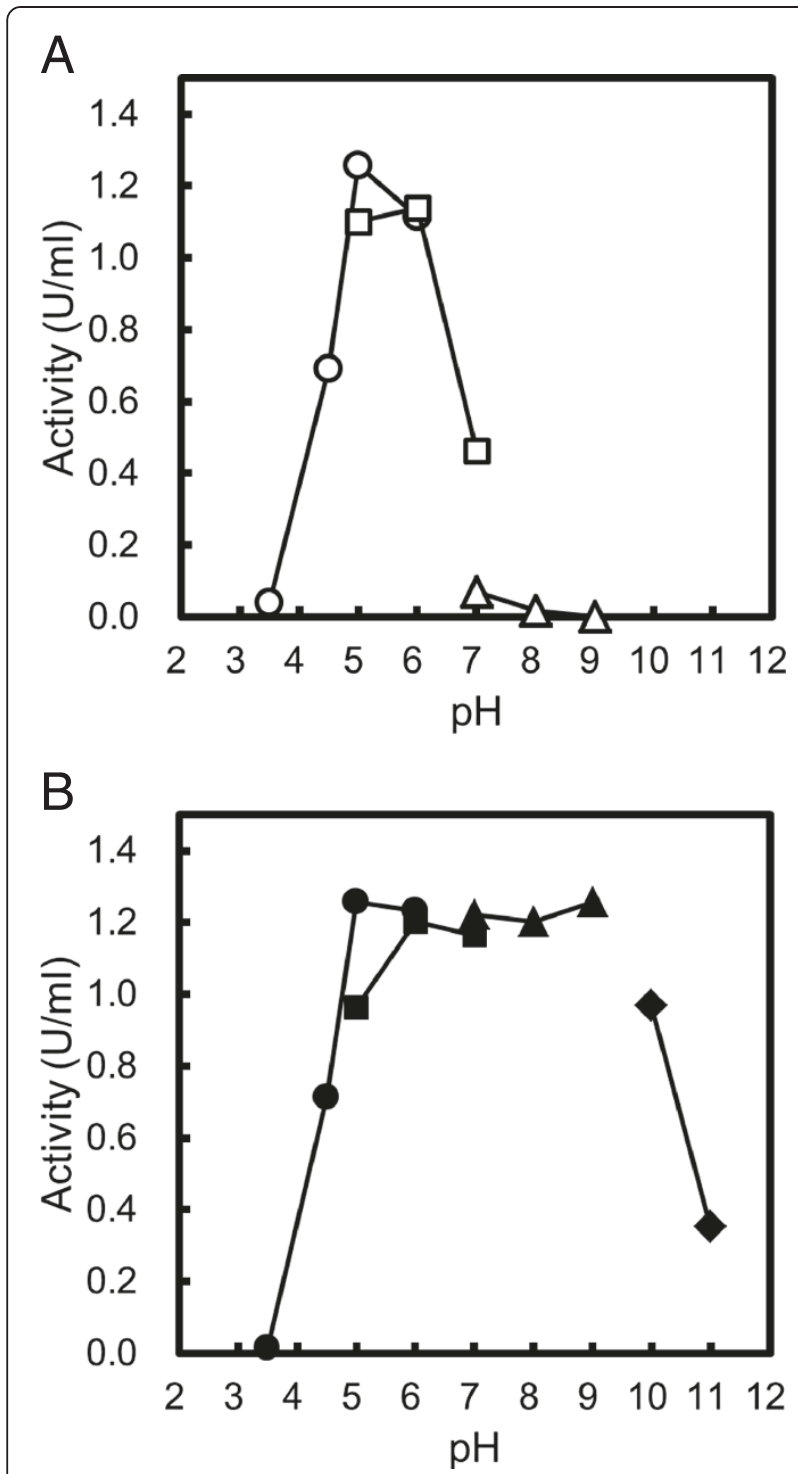

Figure 4 Effects of $\mathrm{pH}$ on the CauloGA activity (A) and stability (B). (A) The activity was measured at $40^{\circ} \mathrm{C}$ in various buffers at different $\mathrm{pH}$ values as follows: $50 \mathrm{mM}$ acetate buffer ( $\mathrm{pH}$ 3.5-6.0, open circle), $50 \mathrm{mM}$ MES-NaOH buffer (pH 5.0-7.0, open square), or 50 mM Tris-HCl buffer (pH 7.0-9.0, open triangle). (B) CauloGA was incubated at $4^{\circ} \mathrm{C}$ for $60 \mathrm{~min}$ at various $\mathrm{pH}$ values as follows: $50 \mathrm{mM}$ acetate buffer (pH 3.5-6.0, closed circle), 50 mM MES-NaOH buffer (pH 5.0-7.0, closed square) or $50 \mathrm{mM}$ Tris-HCl buffer (pH 7.0-9.0, closed triangle), or $50 \mathrm{mM}$ carbonate- $\mathrm{NaOH}$ buffer ( $\mathrm{pH}$ 10-11, closed rhombus). The remaining activity was measured at $40^{\circ} \mathrm{C}$ and $\mathrm{pH}$ 5.0. The values are represented as enzyme activity. Experiments were carried out in triplicate

between $\mathrm{pH} 4.5$ and $\mathrm{pH} 7.0$, at which the enzyme demonstrated more than half of its maximal activity. Figure 4B illustrates the $\mathrm{pH}$ stability curve of CauloGA and shows that the enzyme retained its full activity after treatment for $60 \mathrm{~min}$ at $\mathrm{pH}$ 5.0-9.0.
Substrate specificity and steady-state kinetics of CauloGA The specificity of the CauloGA activity was investigated at $40^{\circ} \mathrm{C}$ in $50 \mathrm{mM}$ acetate buffer ( $\mathrm{pH} 5.0$ ) using various polysaccharides at $0.45 \%(\mathrm{w} / \mathrm{v})$ substrate concentration as follows: starch, pullulan and dextran, and oligosaccharides; maltodextrins, isomaltotriose and panose. CauloGA actively hydrolyzed the substrates with $\alpha-(1 \rightarrow 4)$-glucosidic linkages at the non-reducing end, such as starch, maltose and maltotriose. Conversely, CauloGA showed little (if any) hydrolyzing activity on the substrates with $\alpha-(1 \rightarrow$ 6)-glucosidic linkages, namely, pullulan, dextran and isomaltotriose (Table 1). CauloGA appeared characteristically active on $\alpha$ - $(1 \rightarrow 4)$-glucosidic linkaged substrates like other bacterial and fungal GAs that have been examined for substrate specificity. However, the activities of CauloGA for maltodextrins were lower at $0.45 \%$ than $0.09 \%$ substrate concentration except for starch and maltose (Table 1). To understand the reason for this unusual behavior, we determined the steady-state kinetic parameters of CauloGA for various substrates using a DeltaGraph software by nonlinear regression. Figure $5 \mathrm{~A}$ and Figure $6 \mathrm{~A}$ show the initial rate of the CauloGA reaction at $30^{\circ} \mathrm{C}$ and $\mathrm{pH} 5.0$ using maltose $(0-4.5 \mathrm{mM})$ and maltotriose $(0-0.9 \mathrm{mM})$ as substrates, and Table 2 summarizes the steady-state kinetic parameters for various substrates. In these lower substrate concentration ranges, the CauloGA reaction obeyed the Michaelis-Menten kinetic model. The estimated values of $k_{\mathrm{cat}}$ and $K_{\mathrm{m}}$ were $38.2 \mathrm{~s}^{-1}$ and $0.87 \mathrm{mM}$, and $150 \mathrm{~s}^{-1}$ and $0.16 \mathrm{mM}$, for maltose and maltotriose, respectively, assuming the molecular mass of $96 \mathrm{kDa}$ that was deduced for the Protein A-CauloGA fusion. For other maltodextrins as substrates, the $K_{\mathrm{m}}$ values decreased to $0.03-0.05 \mathrm{mM}$. The CauloGA activity was significantly inhibited when the substrate concentration

Table 1 Comparison of CauloGA activity for starch and maltodextrins

\begin{tabular}{lcc}
\hline & \multicolumn{2}{c}{ Substrate concentration $(\mathbf{w} / \mathbf{v})$} \\
\cline { 2 - 3 } Substrates & $\mathbf{0 . 0 9 \%}$ & $\mathbf{0 . 4 5 \%}$ \\
$\mathbf{U} / \mathbf{m l}, \mathbf{( \% )}$ & $\mathbf{U} / \mathbf{m l},(\%)$ \\
\hline Starch & $1.2(100)$ & $1.6(100)$ \\
Maltose & $0.5(42)$ & $0.5(31)$ \\
Maltotriose & $2.0(167)$ & $0.9(56)$ \\
Maltotetraose & $1.4(117)$ & $0.6(38)$ \\
Maltopentaose & $1.5(125)$ & $0.4(25)$ \\
Pullulan & $\mathrm{ND}^{*}$ & $<0.01(<1)$ \\
Dextran & $\mathrm{ND}^{*}$ & $<0.01(<1)$ \\
Isomaltotriose & $\mathrm{ND}^{*}$ & $<0.01(<1)$ \\
Panose & $\mathrm{ND}^{*}$ & $<0.01(<1)$ \\
\hline
\end{tabular}

The values represent the enzyme activity with starch and maltodextrins as substrates. The values in the parentheses represent the relative activity with its starch-hydrolyzing activity taken as $100 \%$. Experiments were carried out in duplicate or triplicate, and the average values are indicated. *Not determined. 


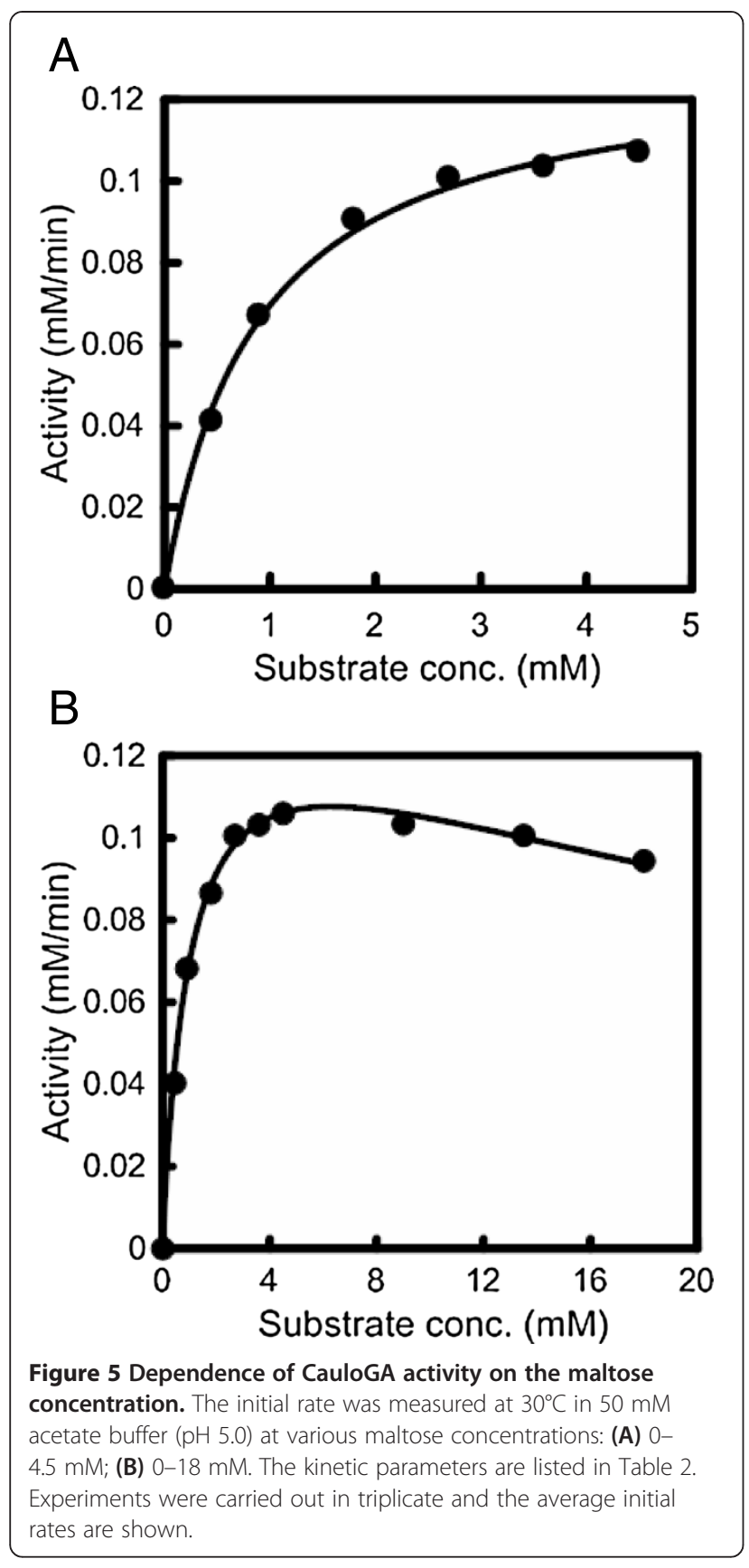

exceeded approximately 10 -fold the $K_{\mathrm{m}}$ value. For instance, inhibition was pronounced at a concentration above $2 \mathrm{mM}$ maltotriose (Figure 6B). The apparent substrate inhibition constant, $K_{\mathrm{i}}$, for maltotriose was approximately $4.2 \mathrm{mM}$ (Table 2). For other maltdextrins, the substrate inhibition was more pronounced and the apparent substrate inhibition constants were approximately $1 \mathrm{mM}$. Higher concentrations of maltose also slightly inhibited the CauloGA reaction, and the estimated $K_{\mathrm{i}}$ value was approximately $38 \mathrm{mM}$ (Figure 5B, Table 2).

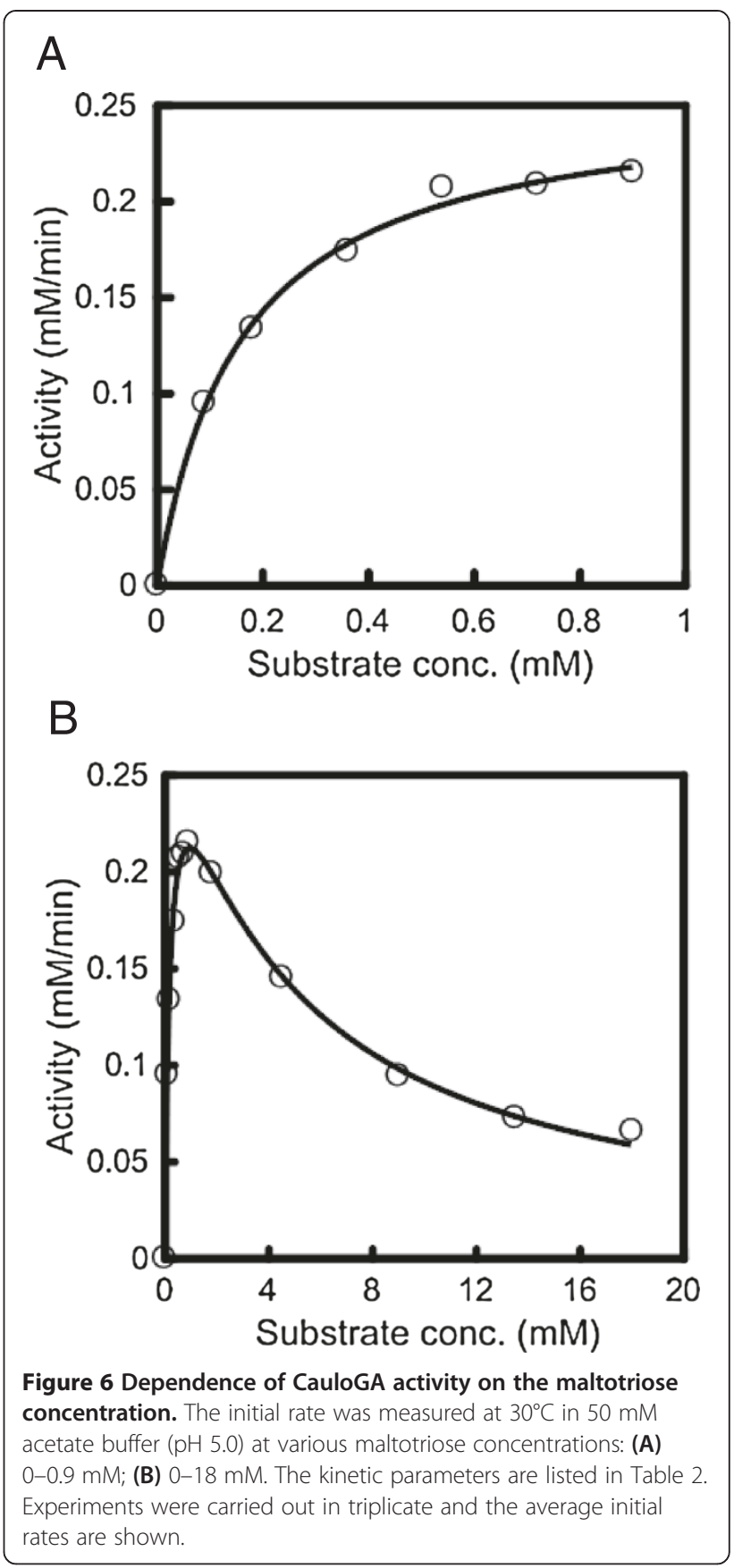

Based on the kinetic data, the subsite affinities $\left(A_{\mathrm{i}}\right)$ of CauloGA were evaluated according to the method of Hiromi et al. (1973), using Equation 1 and Equation 2.

$$
\begin{aligned}
& A_{\mathrm{n}+1}=\mathrm{RT}\left\{\ln \left(k_{\mathrm{cat}} / K_{\mathrm{m}}\right)_{\mathrm{n}+1}-\ln \left(k_{\mathrm{cat}} / K_{\mathrm{m}}\right)_{\mathrm{n}}\right\} \\
& \left(k_{\mathrm{cat}} / K_{\mathrm{m}}\right)_{2}=0.018 k_{\text {int }} \exp \left\{\left(A_{1}+A_{2}\right) / \mathrm{RT}\right\}
\end{aligned}
$$

where $A_{\mathrm{i}}, \mathrm{R}, \mathrm{T}$ and $k_{\text {int }}$ denote the subsite affinity (i: subsite number), gas constant, absolute temperature and intrinsic rate constant, respectively. 
Table 2 Steady-state kinetic parameters of CauloGA at $30^{\circ} \mathrm{C}$, pH 5.0

\begin{tabular}{lcccc}
\hline Substrates & $\boldsymbol{k}_{\text {cat }}^{\mathrm{a}}\left(\mathbf{s}^{-1}\right)$ & $\boldsymbol{K}_{\mathbf{m}}^{\mathrm{a}}(\mathbf{m M})$ & $\begin{array}{c}\boldsymbol{k}_{\text {cat }} / \boldsymbol{K}_{\mathbf{m}} \\
\left(\mathbf{s}^{-1} \mathbf{m M}^{-1}\right)\end{array}$ & $\boldsymbol{K}_{\mathbf{i}}^{\mathbf{b}}(\mathbf{m M})$ \\
\hline Maltose & $38.2 \pm 0.94$ & $0.87 \pm 0.08$ & 43.9 & $38.2 \pm 1.11$ \\
Maltotriose & $150 \pm 4.37$ & $0.16 \pm 0.02$ & 938 & $4.49 \pm 0.31$ \\
Maltotetraose & $155 \pm 0.66$ & $0.14 \pm 0.004$ & 1110 & $1.10 \pm 0.06$ \\
Maltopentaose & $122 \pm 4.21$ & $0.03 \pm 0.008$ & 4070 & $0.92 \pm 0.04$ \\
Maltohexaose & $125 \pm 1.91$ & $0.05 \pm 0.004$ & 2500 & $1.05 \pm 0.08$ \\
Maltoheptaose & $114 \pm 4.57$ & $0.04 \pm 0.003$ & 2850 & $1.25 \pm 0.25$ \\
\hline
\end{tabular}

${ }^{a} k_{\text {cat }}$ and $K_{\mathrm{m}}$ values (means \pm standard deviation) were obtained based on the results with maltose $(0-4.5 \mathrm{mM})$, maltotriose $(0-0.9 \mathrm{mM})$ and maltotetraose to maltoheptaose $(0-0.36 \mathrm{mM})$ as the substrates. Experiments were performed in triplicate.

${ }^{\mathrm{b}} K_{\mathrm{i}}$ values (means \pm standard deviation) were obtained based on the results with maltose to maltotetraose $(0-18 \mathrm{mM})$ and with maltopentaose to maltoheptaose $(0-9 \mathrm{mM})$ as the substrates. Experiments were carried out in triplicate.
The subsite affinities, $A_{3}, A_{4}, A_{5}, A_{6}$ and $A_{7}$ were estimated to be $7.7,0.4,3.2,-1.2$ and $-0.3 \mathrm{~kJ} / \mathrm{mol}$, respectively, from Eq. 1 . The $A_{1}+A_{2}$ value was estimated to be $27.8 \mathrm{~kJ} / \mathrm{mol}$ from Eq. 2 , by assuming $k_{\text {int }}=\left(k_{\text {cat }}\right)_{2}$.

\section{Discussion}

In the Gram-negative bacterium Caulobacter crescentus genome, three putative maltodextrin-related hydrolase genes, cc2282 (GA) (Nierman et al. 2001; Neugebauer et al. 2005; Lohmiller et al. 2008), $c c 2285$ and $c c 2286$ ( $\alpha$-amylases) are assigned in the malA gene cluster that encodes the maltodextrin transport system. However, the functional evidence for this assignment has been lacking. Therefore, the roles and functions of these putative glycoside hydrolase family proteins of $C$. crescentus still remain obscure. In the present work, we cloned the cc2282 gene of C. crescentus, and identified it as the CauloGA gene based on the properties of the gene product that was expressed in $E$. coli as a protein fused with Staphylococcus Protein A at the N-terminus.

\section{Conserved region 1}

\begin{tabular}{|c|c|c|}
\hline CauloGA & 328 & GALIASLSNPWGDTVDATKSSTGYKAVWPRDFY \\
\hline ClostGA & 311 & $G A Y$ I A S L S I PWGDGQGD-DNTGGYHLVWSRDL Y \\
\hline TtGA & 315 & GA Y I A S L S I PWGDGQRD-DNTGGYHLVWSRDLY \\
\hline TtcGA & 331 & GA F I A S LS I PWGEGQGD-ENKGGYHLVWARDLY \\
\hline AawGA & 35 & G I V V A S PS T D N P D - - \\
\hline AgGDase & 303 & GA F I A S L T I PWGQA ASAETHEWG Y HAVWARSMY \\
\hline
\end{tabular}

Conserved region 2

\begin{tabular}{|c|c|c|}
\hline CauloGA & 403 & $Q K S H \vee D G T-P E W \vee G \vee Q L D Q$ \\
\hline ClostGA & 376 & $T W$ I S GK-P YWTG I Q L D \\
\hline TtGA & 380 & QNTW I S \\
\hline TtcGA & 396 & W \\
\hline AawGA & 109 & A Y T G SW GRP QR \\
\hline AgGDase & 370 & 1 \\
\hline
\end{tabular}

\section{Conserved region 3}

\begin{tabular}{|c|c|c|c|}
\hline CauloGA & 475 & PFTQQERWEEQGGHSPSTTAA V I A & 498 \\
\hline ClostGA & 426 & PKTGQERWEE IGGYSPATMAAEVA & 449 \\
\hline TtGA & 430 & $P K T G Q E R W E E$ I GGYSPATMAAEVA & 453 \\
\hline TtcGA & 446 & $P K T G Q E R W E E A G G Y S P A T M A A E \vee A$ & 469 \\
\hline AawGA & 171 & $N Q T G Y D L W E E \vee N G S S F F T$ I A VQHR & 194 \\
\hline AgGDase & 422 & PKTPQERWEETGGYSTSTLASQ IA & 445 \\
\hline
\end{tabular}

\section{Conserved region 4}

\begin{tabular}{|c|c|c|c|}
\hline CauloGA & 629 & $P G W R R Y G \vee D G Y G E D T K T G A N Y G A D N Q M R P G Q R G R \vee W P \mid F$ & 667 \\
\hline ClostGA & 567 & P SWYR YNHDGYGEPSKTELYHGAG- & 598 \\
\hline TtGA & 57 & G Y GE P S K TE L Y H & 602 \\
\hline TtcGA & 58 & G Y GE P A K GE L Y H GA G & 618 \\
\hline AawGA & 301 & V A V GR YPEDSYYN & 320 \\
\hline AgGDase & 563 & $R M W H R Y T Y D G Y G E K A D G S P W D G T$ & 598 \\
\hline
\end{tabular}

\section{Conserved region 5}

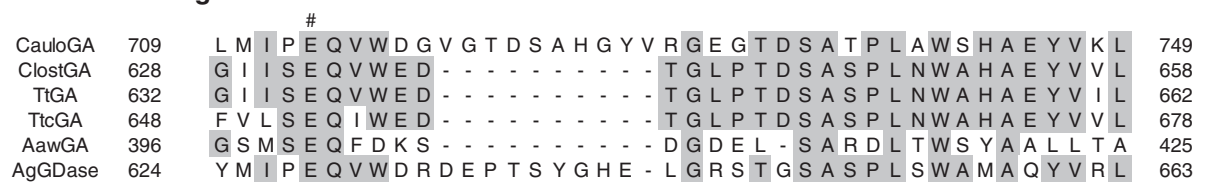

Figure 7 Sequence alignments of the conserved regions (1-5) of CauloGA with other GAs and GDase. The sequences aligned are: CauloGA, C. crescentus CB15 glucoamylase; ClostGA, Clostridium sp. G0005 glucoamylase; TtGA, T. thermosaccharolyticum glucoamylase; TtcGA, T. tengcongensis glucoamylase; AawGA, A. awamori glucoamylase; AgGDase, A. globiformis 142 glucodextranase. The symbol "\#" denotes putative catalytic residues. Identical amino acid residues common to three or more of these enzymes are shaded. 
Based on the deduced amino acid sequence of the cc2282 gene product, it is likely composed of an $\mathrm{N}$-terminal domain and a catalytic domain. The putative catalytic domain of the $c c 2282$ gene product has five conserved regions, which is a common feature shared with other GAs in the literature. The structural characteristics described above are consistent with the notion that the $c c 2282$ gene represents the CauloGA gene. However, functional evidence to verify this notion has been lacking, since we were unable to detect the GA activity in either the culture medium or the cell homogenate of $C$. crescentus CB15. Moreover, it was reported that the $c c 2282$ gene product was not essential for the growth of $C$. crescentus on maltodextrins because inactivation of the $c c 2282$ gene by the $\Omega$ resistance cassette insertion did not reduce the growth rate of $C$. crescentus on maltose, maltotriose or maltotetraose (Lohmiller et al. 2008). The $c c 2282$ gene product may be dispensable in the presence of a sufficient concentration of maltodextrin in the medium. Expression of the gene product in functional form and biochemical characterization of the product is therefore necessary before the gene assignment is finally established.

Although it was difficult to express CauloGA in a soluble and active form in E. coli, we finally succeeded in this study in expressing CauloGA in the soluble and active form in E. coli. The pEZZ18 vector used in this study was originally designed to utilize the Staphylococcus Protein A leader sequence for the secretion of a fusion protein directly into the cell culture medium (Moks et al. 1987). However, in the present study, the fusion protein, ProteinA-CauloGA, was not secreted but was expressed intracellularly in the E. coli HB101 cells. The Protein A-CauloGA fusion protein was also expressed using the pET21 vector, although the expression was lower than that with the pEZZ18 system. This result may imply that having the Protein A moiety as a fusion partner aids in folding and solubilizing the CauloGA moiety. It may be argued that the fusion of the protein A moiety may somehow alter the catalytic properties of the native enzyme protein. However, we consider that this is unlikely, because the trace amount of CauloGA expressed without protein A fusion using the pCold I expression vector showed very similar characteristics with the Protein A-CauloGA fusion product with respect to the substrate specificity and temperature- and $\mathrm{pH}$-dependence. The functional expressions as Protein A-fusion proteins without impairing original catalytic activities were also reported recently on keratinases, lipases and mammalian chitinase (Tiwary and Gupta 2010; Rajput et al. 2012; Kumari and Gupta 2012; Kashimura et al. 2013).

We identified the $c c 2282$ gene product as GA (CauloGA) based on a number of characteristics that the gene product shares with other GAs; for instance, it produces glucose from maltotriose and starch, but not from $\alpha-(1 \rightarrow 6)$ linkaged substrates such as dextran, indicating that $c c 2282$ gene product is not a GDase. Moreover, the released product was identified as the $\beta$-anomer of glucose. These results indicate that CauloGA is an exo-type hydrolytic enzyme with the inverting mechanism, that is, a GA. In addition, CauloGA is active in an acidic environment ( $\mathrm{pH} 4.5-7.0)$. This is similar to other GAs that have conserved glutamic acid residues, that are involved in the hydrolysis as the general acid and base catalysts, in the conserved regions 3 and 5 of the catalytic domain (Sierks et al. 1990; Harris et al. 1993; Frandsen et al. 1994; Ohnishi et al. 1994). The two glutamic acid residues, Glu483 and Glu713, in the conserved regions 3 and 5 of the putative catalytic domain of CauloGA, located at positions corresponding to those conserved glutamic acid residues in other GAs (Figure 7), may be involved in the hydrolysis of the substrate similarly to those in other GAs. CauloGA has a strong preference for the substrates with $\alpha-(1 \rightarrow 4)$-glucosidic linkages, such as maltose, maltotriose and starch, to those with $\alpha$-(1 $\rightarrow 6)$-glucosidic linkages. It is noted that the optimal temperature of CauloGA was approximately $40^{\circ} \mathrm{C}$, and

Table 3 Comparison of kinetic parameters of various GAs with maltose and maltotiose as the substrates

\begin{tabular}{|c|c|c|c|c|c|c|c|}
\hline \multirow[b]{3}{*}{ Enzymes } & \multicolumn{6}{|c|}{ Substrates } & \multirow{3}{*}{$\begin{array}{l}\text { Conditions } \\
\text { Temp }\left({ }^{\circ} \mathrm{C}\right), \mathrm{pH}\end{array}$} \\
\hline & \multicolumn{3}{|c|}{ Maltose } & \multicolumn{3}{|c|}{ Maltotriose } & \\
\hline & $k_{\text {cat }}\left(\mathrm{s}^{-1}\right)$ & $K_{\mathrm{m}(\mathrm{mM})}$ & $k_{\text {cat }} / K_{\mathrm{m}}\left(\mathrm{s}^{-1} \mathrm{mM}^{-1}\right)$ & $k_{\text {cat }}\left(\mathrm{s}^{-1}\right)$ & $K_{\mathrm{m}}(\mathrm{mM})$ & $k_{\text {cat }} / K_{\mathrm{m}}\left(\mathrm{s}^{-1} \mathrm{mM}^{-1}\right)$ & \\
\hline CauloGA & 38.2 & 0.87 & 43.9 & 150 & 0.16 & 938 & $30,5.0$ \\
\hline ClostGA & 10.4 & 3.67 & 2.83 & 74.1 & 0.69 & 107 & $25,4.5$ \\
\hline TGA & 16.9 & 0.10 & 167 & 76.4 & 0.38 & 201 & $40,6.5$ \\
\hline TtcGA & 149 & 13.4 & 11.1 & 368 & 1.93 & 191 & $75,5.0$ \\
\hline AawGA & 14.4 & 1.73 & 8.3 & 62 & 0.73 & 86 & $50,4.4$ \\
\hline AmyC & 9.3 & 0.53 & 17.5 & 54.7 & 0.49 & 112 & $40,5.5$ \\
\hline
\end{tabular}

The kinetic parameters of various GAs and the conditions for activity measurements are taken from the sources as follows: CauloGA (C. crescentus CB15 glucoamylase), this study; ClostGA (Clostridium sp. G0005 glucoamylase; Ohnishi et al. 1992); TGA (Thermoactinomyces vulgaris R-47 glucoamylase; Ichikawa et al. 2004); TtcGA (Thermoanaerobacterium tengcongensis glucoamylase; Zheng et al. 2010); AawGA (Aspergillus awamori glucoamylase; Sierks et al. 1989); AmyC (Rhizopus oryzae glucoamylase; Mertens et al. 2010) 
irreversible heat-inactivation became noticeable above $40^{\circ}$ $\mathrm{C}$ as shown in Figure 3. However, the enzyme seems to begin partially, though reversibly, inactivated at temperatures above $30^{\circ} \mathrm{C}$. This is suggested by the observation that the Arrhenius plot was apparently linear below $30^{\circ} \mathrm{C}$, but that deviation from linearity was noted above $30^{\circ} \mathrm{C}$ (Additional figure 4: Figure S4). For this reason, we carried out kinetic experiments at $30^{\circ} \mathrm{C}$ and $\mathrm{pH} 5.0$.

When the kinetic constants of CauloGA, with maltotriose as a substrate, are compared with those of other GAs, $k_{\text {cat }}$ was higher and $K_{\mathrm{m}}$ was lower, and consequently, the $k_{\mathrm{cat}} / K_{\mathrm{m}}$ value of CauloGA was the highest value among the GAs reported (Table 3). With maltose as a substrate, $k_{\text {cat }}$ and $K_{\mathrm{m}}$ were slightly higher and lower, respectively, than other GAs. In addition, CauloGA had significantly higher affinities for maltodextrins composed of 5-7 glucose units than shorter maltodextrins (Table 2). The lower $K_{\mathrm{m}}$ values of CauloGA compared with other GAs may imply that the enzyme plays a role in the environmental conditions of $C$. crescentus inhabitation in which the availability of the substrates is usually limited. Subsite affinities $A_{1}+A_{2}, A_{3}, A_{4}$ and $A_{5}$ estimated from the kinetic parameters of CauloGA were positive, but $A_{6}$ and $A_{7}$ were negative. The values of $A_{1}+A_{2}, A_{3}$ and $A_{5}$ imply a high affinity of the corresponding subsites to glucose residues of substrates. These subsite affinities may suggest that the CauloGA molecule provides five subsites for substrate binding, although we have to wait crystallographic elucidation of the enzyme structure for definite conclusion.

Another remarkable feature of CauloGA was the extensive apparent substrate inhibition by maltotriose at concentrations that were 10 -fold higher than the $K_{\mathrm{m}}$ value. A similar but more pronounced inhibition was also observed with various maltodextrins as substrates, but the inhibition was only marginal with maltose as a substrate. In view of the report on fungal GA, AmyC, describing the inhibition resulting from the accumulation of enzyme-product intermediates (Mertens et al. 2010), the inhibition of CauloGA by substrates at high concentration ranges may actually be a result of the product inhibition rather than the substrate inhibition. With maltotriose and maltotetraose as substrates, we may suppose that the reaction products, maltose and maltotriose, respectively, were slowly released from CauloGA because of their high affinity, while glucose, the product of maltose hydrolysis, was released more rapidly. However, the precise mechanisms of this inhibition may be more complicated and remain to be elucidated in future studies.

Despite the similarity of the catalytic properties of CauloGA with other GAs, it is much less thermostable than other thermophilic GAs. The maltotriose-hydrolyzing activity of CauloGA was optimal at $40^{\circ} \mathrm{C}$ (Figure 3A), and the enzyme was labile at temperatures above $40^{\circ} \mathrm{C}$ (Figures $3 \mathrm{~B}$ and S3). The thermolabile characteristics of CauloGA may be related to the insertions of approximately ten amino acid residues in both the putative $\mathrm{N}$-terminal and the catalytic domains of CauloGA that make its molecular mass (approximately $82 \mathrm{kDa}$ ) slightly larger than other GAs. It is also interesting that amino acid composition was considerably different between CauloGA and other bacterial and archaeal thermophilic GAs. CauloGA contained more alanine (14.5\%), glycine (10.2\%) and threonine (7.8\%) but less isoleucine (2.6\%) asparagine (1.9\%) and tyrosine (3.9\%) than thermophilic GAs which are composed of less alanine (4.6-8.8\%), glycine (5.3-8.7\%) and threonine (3.9-4.9\%), and more isoleucine (4.9-10.6\%), asparagine (2.3-7.9\%) and tyrosine (3.5-7.7\%), respectively, although it is unclear at present how such differences are related to the thermolability of CauloGA. Such a trend was noted not only with the overall amino acid composition but also with the amino acid composition of the putative catalytic domain and of the conserved regions of GAs (Figure 7).

In conclusion, we were able to unambiguously demonstrate that the $c c 2282$ gene product represents CauloGA based on its catalytic properties. CauloGA is active at lower substrate concentrations and at lower temperatures compared with the thermophilic GAs reported. The mechanisms underlying the inhibition noted at elevated substrate concentration ranges and the structural basis of the thermolability should be investigated further. These studies would lead to a deeper insight into the relationships between the function and the structure of GA and GH15 family enzymes and also contribute toward the understanding of the glycoside hydrolase system of $C$. crescentus.

\section{Additional files}

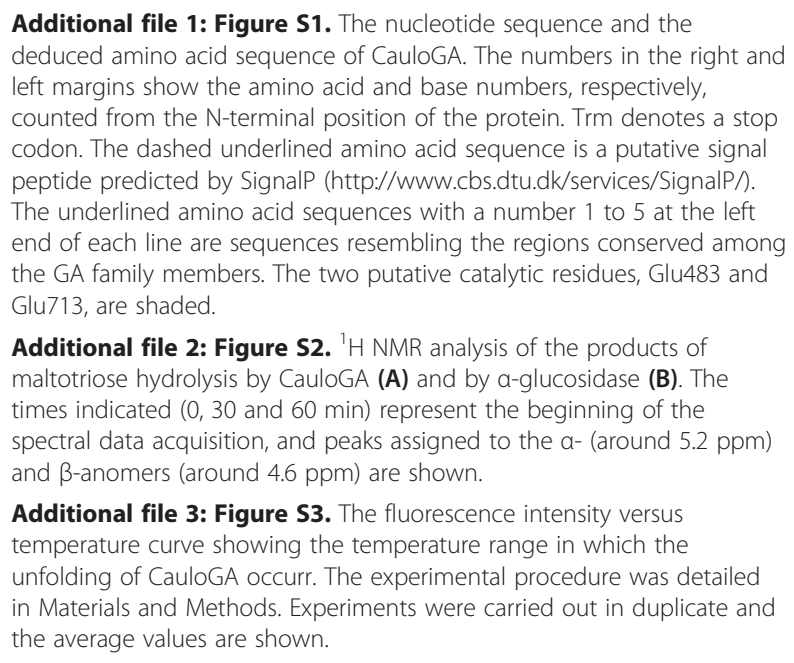
peptide predicted by SignalP (http://www.cbs.dtu.dk/services/SignalP/) The underlined amino acid sequences with a number 1 to 5 at the left end of each line are sequences resembling the regions conserved among the GA family members. The two putative catalytic residues, Glu483 and Glu713, are shaded.

Additional file 2: Figure S2. ${ }^{1} \mathrm{H}$ NMR analysis of the products of maltotriose hydrolysis by CauloGA (A) and by a-glucosidase (B). The times indicated $(0,30$ and $60 \mathrm{~min}$ ) represent the beginning of the spectral data acquisition, and peaks assigned to the a- (around $5.2 \mathrm{ppm}$ ) and $\beta$-anomers (around $4.6 \mathrm{ppm}$ ) are shown.

Additional file 3: Figure $\mathbf{5 3}$. The fluorescence intensity versus temperature curve showing the temperature range in which the unfolding of CauloGA occurr. The experimental procedure was detailed in Materials and Methods. Experiments were carried out in duplicate and the average values are shown. 
Additional file 4: Figure S4. Arrhenius plot of the initial rate of CauloGA reaction toward maltotriose. The values were estimated from the results in Figure $3 \mathrm{~A}$.

\section{Competing interests}

The authors declare that the research was conducted in the absence of any commercial or financial relationships that could be construed as potential conflicts of interest.

\section{Acknowledgments}

We thank H. Harakawa and M. Yamamoto for technical assistance. This work was supported in part by the Project Research Grant from the Research Institute for Science and Technology, Kogakuin University.

\section{Author details}

'Department of Applied Chemistry, Kogakuin University, 2,665-1 Nakano-cho, Hachioji, Tokyo 192-0015, Japan. ${ }^{2}$ Translational Medical Research Center, Tokyo Metropolitan Institute of Medical Science, 2-1-6 Kami-kitazawa, Setagaya-ku, Tokyo 156-8506, Japan.

\section{Received: 29 November 2013 Accepted: 2 December 2013}

Published: 27 January 2014

\section{References}

Aleshin AE, Feng PH, Honzatko RB, Reilly PJ (2003) Crystal structure and evolution of a prokaryotic glucoamylase. J Mol Biol 327:61-73, doi:10.1016/50022-2836 (03)00084-6

Bradford MM (1976) A rapid and sensitive method for the quantitation of microgram quantities of protein utilizing the principle of protein-dye binding. Anal Biochem 72:248-254, doi:10.1016/0003-2697(76)90527-3

Corrêa JM, Graciano L, Abrahão J, Loth EA, Gandra RF, Kadowaki MK, Henn C, Simão Rde C (2012) Expression and characterization of a GH39 $\beta$-xylosidase II from Caulobacter crescentus. Appl Biochem Biotechnol 168:2218-2229, doi:10.1007/s12010-012-9931-1

Coutinho PM, Reilly PJ (1997) Glucoamylase structural, functional, and evolutionary relationships. Proteins 29:334-347, doi:10.1002/(SICI)1097-0134 (199711)

Dock C, Hess M, Antranikian G (2008) A thermoactive glucoamylase with biotechnological relevance from the thermoacidophilic Euryarchaeon Thermoplasma acidophilum. Appl Microbiol Biotechnol 78:105-114, doi:10.1007/s00253-007-1293-1

Ducki A, Grundmann O, Konermann L, Mayer F, Hoppert M (1998) Glucoamylase from Thermoanaerobacterium thermosaccharolyticum: sequence studies and analysis of the macromolecular architecture of the enzyme. J Gen Appl Microbiol 44:327-335, doi:10.2323/jgam.44.327

Frandsen TP, Dupont C, Lehmbeck J, Stoffer B, Sierks MR, Honzatko RB, Svensson B (1994) Site-directed mutagenesis of the catalytic base glutamic acid 400 in glucoamylase from Aspergillus niger and of tyrosine 48 and glutamine 401, both hydrogen-bonded to the gamma-carboxylate group of glutamic acid 400. Biochemistry 33:13808-13816, doi:10.1021/bi00250a035

Ganghofner D, Kellermann J, Staudenbauer WL, Bronnenmeier K (1998) Purification and properties of an amylopullulanase, a glucoamylase, and an alpha-glucosidase in the amylolytic enzyme system of Thermoanaerobacterium thermosaccharolyticum. Biosci Biotechnol Biochem 62:302-308, doi:10.1271/bbb.62.302

Gloster TM, Turkenburg JP, Potts JR, Henrissat B, Davies GJ (2008) Divergence of catalytic mechanism within a glycosidase family provides insight into evolution of carbohydrate metabolism by human gut flora. Chem Biol 15:1058-1067, doi:10.1016/j.chembiol..09.005

Graciano L, Corrêa JM, Gandra RF, Seixas FA, Kadowaki MK, Sampaio SC, Silva JL, Osaku CA, Simão Rde C (2012) The cloning, expression, purification, characterization and modeled structure of Caulobacter crescentus $\beta$-Xylosidase I. World J Microbiol Biotechnol 28:2879-2888, doi:10.1007/s11274-012-1099-x

Harris EM, Aleshin AE, Firsov LM, Honzatko RB (1993) Refined structure for the complex of 1-deoxynojirimycin with glucoamylase from Aspergillus awamori var. X100 to 2.4-Å resolution. Biochemistry 32:1618-1626, doi:10.1021/bi00057a028

Hiromi K, Nitta Y, Numata C, Ono S (1973) Subsite affinities of glucoamylase: examination of the validity of the subsite theory. Biochim Biophys Acta 302:362-375
Ichikawa K, Tonozuka T, Uotsu-Tomita R, Akeboshi H, Nishikawa A, Sakano Y (2004) Purification, characterization, and subsite affinities of Thermoactinomyces vulgaris R-47 maltooligosaccharide-metabolizing enzyme homologous to glucoamylases. Biosci Biotechnol Biochem 68:413-420, doi:10.1271/bbb.68.413

Kashimura A, Okawa K, Ishikawa K, Kida Y, Iwabuchi K, Matsushima Y, Sakaguchi M, Sugahara Y, Oyama F (2013) Protein A-mouse acidic mammalian chitinase-V5-His expressed in periplasmic space of Escherichia coli possesses chitinase functions comparable to CHO-expressed protein. PLOS ONE 8: e78669, doi:10.1371/journal.pone.0078669

Kim MS, Park JT, Kim YW, Lee HS, Nyawira R, Shin HS, Park CS, Yoo SH, Kim YR, Moon TW, Park KH (2004) Properties of a novel thermostable glucoamylase from the hyperthermophilic archaeon Sulfolobus solfataricus in relation to starch processing. Appl Environ Microbiol 70:3933-3940, doi:10.1128/ AEM.70.7.3933-3940.2004

Kumar P, Satyanarayana T (2009) Microbial glucoamylases: characteristics and applications. Crit Rev Biotechnol 29:225-255, doi:10.1080/07388550903136076

Kumari A, Gupta R (2012) Extracellular expression and characterization of thermostable lipases, LIP8, LIP14 and LIP18, from Yarrowia lipolytica. Biotechnol Lett 34:1733-1739, doi:10.1007/s10529-012-0958-8

Laemmli UK (1970) Cleavage of structural proteins during the assembly of the head of bacteriophage T4. Nature 227:680-685, doi:10.1038/227680a0

Lohmiller S, Hantke K, Patzer SI, Braun V (2008) TonB-dependent maltose transport by Caulobacte rcrescentus. Microbiology 154:1748-1754, doi:10.1099/mic.0.2008/017350-0

Mertens JA, Braker JD, Jordan DB (2010) Catalytic properties of two Rhizopus oryzae 99-880 glucoamylase enzymes without starch binding domains expressed in Pichia pastoris. Appl Biochem Biotechnol 162:2197-2213, doi:10.1007/s12010-010-8994-0

Mizuno M, Tonozuka T, Suzuki S, Uotsu-Tomita R, Kamitori S, Nishikawa A, Sakano Y (2004) Structural insights into substrate specificity and function of glucodextranase. J Biol Chem 279:10575-10583, doi:10.1074/jbc.M310771200

Moks T, Abrahmsén L, Holmgren E, Bilich M, Olsson A, Uhlén M, Pohl G, Sterky C, Hultberg H, Josephson S, Holmgren A, Jörnvall H, Nilsson B (1987) Expression of human insulin-like growth factor I in bacteria: use of optimized gene fusion vectors to facilitate protein purification. Biochemistry 26:5239-5244, doi:10.1021/bi00391a005

Neugebauer H, Herrmann C, Kammer W, Schwarz G, Nordheim A, Braun V (2005) ExbBD-dependent transport of maltodextrins through the novel MalA protein across the outer membrane of Caulobacter crescentus. J Bacteriol 187:8300-8311, doi:10.1128/JB.187.24.8300-8311.2005

Nierman WC, Feldblyum TV, Laub MT, Paulsen IT, Nelson KE, Eisen JA, Heidelberg JF, Alley MR, Ohta N, Maddock JR, Potocka I, Nelson WC, Newton A, Stephens C, Phadke ND, Ely B, DeBoy RT, Dodson RJ, Durkin AS, Gwinn ML, Haft DH, Kolonay JF, Smit J, Craven MB, Khouri H, Shetty J, Berry K, Utterback T, Tran K, Wolf A, Vamathevan J, Ermolaeva M, White O, Salzberg SL, Venter JC, Shapiro L, Fraser CM (2001) Complete genome sequence of Caulobacter crescentus. Proc Natl Acad Sci USA 98:4136-4141, doi:10.1073/pnas.061029298

Niesen FH, Berglund H, Vedadi M (2007) The use of differential scanning fluorimetry to detect ligand interactions that promote protein stability. Nat Protoc 2:2212-2221, doi:10.1038/nprot.2007.321

Ohnishi H, Kitamura H, Minowa T, Sakai H, Ohta T (1992) Molecular cloning of a glucoamylase gene from a thermophilic Clostridium and kinetics of the cloned enzyme. Eur J Biochem 207:413-418, doi:10.1111/j.1432-1033.1992. tb17064.x

Ohnishi H, Matsumoto H, Sakai H, Ohta T (1994) Functional roles of Trp337 and Glu632 in Clostridium glucoamylase, as determined by chemical modification, mutagenesis, and the stopped-flow method. J Biol Chem 269:3503-3510

Poindexter JS (1964) Biological properties and classification of the Caulobacter group. Bacteriol Rev 28:231-295

Rajput R, Tiwary E, Sharma R, Gupta R (2012) Swapping of pro-sequences between keratinases of Bacillus licheniformis and Bacillus pumilus: altered substrate specificity and thermostability. Enzyme Microb Technol 51:131-138, doi:10.1016/j.enzmictec.2012.04.010

Sambrook J, Russell DW (2001) Molecular cloning, a laboratory manual 3rd edition. Cold Spring Harbor Laboratory Press, Cold Spring Harbor

Serour E, Antranikian G (2002) Novel thermoactive glucoamylases from the thermoacidophilic archaea Thermoplasma acidophilum, Picrophilus torridus and Picrophilus oshimae. Antonie Van Leeuwenhoek 81:73-83, doi:10.1023/ A: 1020525525490

Sierks MR, Ford C, Reilly PJ, Svensson B (1989) Site-directed mutagenesis at the active site Trp120 of Aspergillus awamori glucoamylase. Protein Eng 2:621-625 
Sierks MR, Ford C, Reilly PJ, Svensson B (1990) Catalytic mechanism of fungal glucoamylase as defined by mutagenesis of Asp176, Glu179 and Glu180 in the enzyme from Aspergillus awamori. Protein Eng 3:193-198, doi:10.1093/ protein/3.3.193

Song N, Cai HY, Yan ZS, Jiang HL (2013) Cellulose degradation by one mesophilic strain Caulobacter sp. FMC1 under both aerobic and anaerobic conditions. Bioresour Technol 131:281-287, doi:10.1016/j.biortech.2013.01.003

Takeshima-Futagami T, Sakaguchi M, Uehara E, Aoki K, Ishida N, Sanai Y, Sugahara Y, Kawakita M (2012) Amino acid residues important for CMP-sialic acid recognition by the CMP-sialic acid transporter: analysis of the substrate specificity of UDP-galactose/CMP-sialic acid transporter chimeras. Glycobiology 22:1731-1740, doi:10.1093/glycob/cws116

Tiwary E, Gupta R (2010) Extracellular expression of keratinase from Bacillus licheniformis ER-15 in Escherichia coli. J Agric Food Chem 58:8380-8385, doi:10.1021/jf100803g

Uotsu-Tomita R, Tonozuka T, Sakai H, Sakano Y (2001) Novel glucoamylase-type enzymes from Thermoactinomyces vulgaris and Methanococcus jannaschii whose genes are found in the flanking region of the alpha-amylase genes. Appl Microbiol Biotechnol 56:465-473, doi:10.1007/s002530100609

Zheng Y, Xue Y, Zhang Y, Zhou C, Schwaneberg U, Ma Y (2010) Cloning, expression, and characterization of a thermostable glucoamylase from Thermoanaerobacter tengcongensis MB4. Appl Microbiol Biotechnol 87:225-233, doi:10.1007/s00253-010-2439-0

doi:10.1186/2191-0855-4-5

Cite this article as: Sakaguchi et al:: Glucoamylase of Caulobacter crescentus CB15: cloning and expression in Escherichia coli and functional identification. AMB Express 2014 4:5.

\section{Submit your manuscript to a SpringerOpen ${ }^{\circ}$ journal and benefit from:}

- Convenient online submission

- Rigorous peer review

- Immediate publication on acceptance

- Open access: articles freely available online

- High visibility within the field

- Retaining the copyright to your article 